University of Nebraska - Lincoln

DigitalCommons@University of Nebraska - Lincoln

Faculty Papers and Publications in Animal

Science

Animal Science Department

January 1982

\title{
EFFECT OF TALLOW AND CHOLINE CHLORIDE ADDITION TO THE DIET OF SOWS ON MILK COMPOSITION, MILK YIELD AND PREWEANING PIG PERFORMANCE
}

\author{
R. D. Boyd \\ University of Nebraska-Lincoln \\ B. D. Moser \\ University of Nebraska-Lincoln \\ E. R. Peo Jr. \\ University of Nebraska-Lincoln \\ A. R. Lewis \\ University of Nebraska-Lincoln \\ R. K. Johnson \\ University of Nebraska-Lincoln, rjohnson5@unl.edu
}

Follow this and additional works at: https://digitalcommons.unl.edu/animalscifacpub

Part of the Animal Sciences Commons

Boyd, R. D.; Moser, B. D.; Peo, E. R. Jr.; Lewis, A. R.; and Johnson, R. K., "EFFECT OF TALLOW AND CHOLINE CHLORIDE ADDITION TO THE DIET OF SOWS ON MILK COMPOSITION, MILK YIELD AND PREWEANING PIG PERFORMANCE" (1982). Faculty Papers and Publications in Animal Science. 82. https://digitalcommons.unl.edu/animalscifacpub/82

This Article is brought to you for free and open access by the Animal Science Department at DigitalCommons@University of Nebraska - Lincoln. It has been accepted for inclusion in Faculty Papers and Publications in Animal Science by an authorized administrator of DigitalCommons@University of Nebraska - Lincoln. 


\title{
EFFECT OF TALLOW AND CHOLINE CHLORIDE ADDITION TO THE DIET OF SOWS ON MILK COMPOSITION, MILK YIELD AND PREWEANING PIG PERFORMANCE ${ }^{1,2}$
}

\author{
R. D. Boyd ${ }^{3}$, B. D. Moser, E. R. Peo, Jr., ${ }^{4}$ \\ A. J. Lewis and R. K. Johnson \\ University of Nebraska, Lincoln 68583
}

\begin{abstract}
Summary
Four trials were conducted with a total of 188 crossbred sows to determine the effect of feeding diets supplemented with tallow (0 or $8 \%)$ and choline chloride $(220$ or $770 \mathrm{mg} / \mathrm{kg}$ diet) prior to parturition and during lactation on preweaning pig performance. On d 100 of gestation, sows were allotted to four factorially arranged dietary treatments: $0 \%$ tallow-220 $\mathrm{mg} / \mathrm{kg}$ choline chloride, $0 \%$ tallow-770 $\mathrm{mg} / \mathrm{kg}$ choline chloride, $8 \%$ tallow- $220 \mathrm{mg} / \mathrm{kg}$ choline chloride, $8 \%$ tallow-770 mg $/ \mathrm{kg}$ choline chloride. Diets without tallow were fed at the rate of $1.82 \mathrm{~kg} / \mathrm{d}$ with an additional $.18 \mathrm{~kg} / \mathrm{d}$ of cornstarch, whereas sows receiving diets supplemented with tallow were fed $1.82 \mathrm{~kg} / \mathrm{d}$. Daily metabolizable energy intake was constant for all diets (approximately $6,240 \mathrm{kcal}$ ). Following parturition, the diets were fed ad libitum for a 21-d lactation period. Pig survival to $21 \mathrm{~d}$, in relation to the number of pigs born alive/litter, did not differ significantly between litters from sows receiving tallow $(94.0 \%)$ and litters from sows receiving the control diet (92.5\%). Although not significantly different, there was a trend toward slightly heavier pigs $(6.35$ vs $6.11 \mathrm{~kg})$ and litters $(53.97$ vs 51.94 $\mathrm{kg}$ ) after the 21 -d lactation period in the groups nursing sows receiving tallow-supplemented diets. Litter performance was not improved by
\end{abstract}

\footnotetext{
'Published as Paper No. 6556, Journal Series, Nebraska Agr. Exp. Sta.

${ }^{2}$ Dept. of Anim. Sci. The authors wish to express appreciation to the Fats and Proteins Research Foun. dation, Des Plaines, IL, for partial financial support of this project.

${ }^{3}$ Present address: Dept. of Anim. Sci., Cornell Univ., Ithaca, NY.

${ }^{4}$ Person to whom reprint requests should be directed.
}

the addition of choline to sows' diets. A second study was conducted to measure the effect of energy source on milk yield and composition. Twelve crossbred sows were allotted to two dietary treatments ( 0 and $8 \%$ tallow), each supplemented with $770 \mathrm{mg}$ choline chloride $/ \mathrm{kg}$ of diet. The composition of colostrum and milk was determined on d 0,9 and 18, and milk yield was measured on d 12 and 19 . Throughout the lactation period, sows fed the tallow supplemented diet produced higher concentrations of total milk solids $(22.15 \%, \mathrm{P}<.10)$ and fat $(14.9 \%, P<.01)$ than the control group (21.37 and $12.0 \%$, respectively). Milk protein content, averaged over the lactation period, was lower $(\mathrm{P}<.10)$ for sows receiving tallow $(8.60$ vs $9.22 \%$ ); however, the depression appeared to be related to the colostrum samples, because values for the two treatment groups were similar on $d 9$ and 18. The mean milk yield was $9.44 \mathrm{~kg} / \mathrm{d}$ for sows receiving tallow and 8.72 $\mathrm{kg} / \mathrm{d}$ for those fed the control diet. Therefore, not only did sows in the tallow group produce a greater concentration of milk solids and fat, but the total quantity of the milk constituents available to the offspring was increased.

(Key Words: Swine, Tallow, Choline, Pig Survival, Milk Yield, Milk Composition.)

\section{Introduction}

Thirteen to $25 \%$ of all live-born pigs fail to survive the preweaning period, which represents a large economic loss to the swine industry (Stanton and Carroll, 1974). Failure to ingest a sufficient quantity of energy substrates has been recognized as an important factor in baby pig mortality (Friend, 1974; Hartsock and Graves, 1976).

For the past several years, scientists have attempted to improve the energy status of pigs, 
both in utero and through alteration of milk composition, by supplementation of maternal diets with lipids. Initial research by Seerley et al. (1974) evoked interest in adding fat to the diet of gravid and lactating swine when they reported that survival of preweaning pigs $(21 \mathrm{~d})$ was improved markedly by the addition of corn oil to the diet of pregnant sows. Since then, a number of experiments have been conducted to evaluate the effect of supplementing sow diets [gestation and(or) lactation] with fat or oil, and the question of whether there is a beneficial effect on pig survival and thus litter size at weaning has become a matter of controversy. Cast et al. (1977) reported an additional improvement in survival from an increase in the level of choline chloride in tallow-supplemented sow diets, suggesting a possible tallow. choline interaction.

Objectives of the present study were (1) to determine the effect of adding tallow (8\%) to the sow's diet from late gestation through lactation on preweaning pig performance, milk composition and yield, and (2) to further evaluate a possible choline-tallow interaction.

\section{Experimental Procedure}

Exp. 1. Four trials, involving a total of 188 litters from crossbred sows (first through third parity), were conducted to determine the effect of feeding diets supplemented with tallow $(0$ or $8 \%$ ) and choline chloride (220 or 770 $\mathrm{mg} / \mathrm{kg}$ diet) prior to parturition and during lactation on preweaning pig performance. All sows received $1.82 \mathrm{~kg}$ of a corn-soybean meal diet (14\% protein) fortified with vitamins and minerals daily until d 100 of gestation. On d 100 of the gestation period, sows were allotted within parity to four factorially arranged dietary treatments (table 1): $0 \%$ tallow- $220 \mathrm{mg} / \mathrm{kg}$ choline chloride, $0 \%$ tallow $-770 \mathrm{mg} / \mathrm{kg}$ choline chloride, $8 \%$ tallow- $220 \mathrm{mg} / \mathrm{kg}$ choline chloride and $8 \%$ tallow-770 $\mathrm{mg} / \mathrm{kg}$ choline chloride. Subsequently, sows were placed in farrowing crates and dietary treatments initiated. Diets without tallow were fed at the rate of $1.82 \mathrm{~kg} / \mathrm{d}$ with an additional $.18 \mathrm{~kg} / \mathrm{d}$ of cornstarch, while diets containing tallow were fed at the rate of 1.82 $\mathrm{kg} / \mathrm{d}$. The daily metabolizable energy intake was held constant across diets, at approximately $6,240 \mathrm{kcal}$. Following parturition, the

TABLE 1. DIET COMPOSITION AND REGIMEN

(EXP. 1 AND 2)

\begin{tabular}{|c|c|c|c|c|}
\hline \multirow[b]{3}{*}{ Ingredients } & \multicolumn{2}{|c|}{$0 \%$ tallow } & \multicolumn{2}{|c|}{$8 \%$ tallow } \\
\hline & \multicolumn{4}{|c|}{ Choline chloride, $\mathrm{mg} / \mathrm{kg}$} \\
\hline & 220 & 770 & 220 & 770 \\
\hline $\begin{array}{l}\text { Ground yellow corn (IFN 4-03-005) } \\
\text { Tallow, bleachable fancy (IFN 4-07-880) }\end{array}$ & 69.82 & 69.82 & $\begin{array}{r}59.83 \\
8.00\end{array}$ & $\begin{array}{r}59.83 \\
8.00\end{array}$ \\
\hline Soybean meal (IFN 5-04-612) & 15.47 & 15.47 & 17.53 & 17.53 \\
\hline Beet pulp (IFN 4-00-669) & 10.00 & 10.00 & 10.00 & 10.00 \\
\hline Dicalcium phosphate (IFN 6-01-080) & 2.67 & 2.67 & 2.76 & 2.76 \\
\hline Calcium carbonate (IFN 6-01-069) & .38 & .38 & .30 & .30 \\
\hline Monosodium phosphate & .08 & .08 & & \\
\hline Sodium chloride (iodized) & .50 & .50 & .50 & .50 \\
\hline Trace mineral premix ${ }^{a}$ & .08 & .08 & .08 & .08 \\
\hline Vitamin premix $b$ & 1.00 & 1.00 & 1.00 & 1.00 \\
\hline Total & 100.00 & 100.00 & 100.00 & 100.00 \\
\hline \multicolumn{5}{|l|}{ Gestation intake, $\mathrm{kg} / \mathrm{d}$} \\
\hline Diet & 1.82 & 1.82 & 1.82 & 1.82 \\
\hline Cornstarch & .18 & .18 & & \\
\hline $\mathrm{ME}, \mathrm{kcal} / \mathrm{d}^{\mathrm{c}}$ & 6,240 & 6,240 & 6,240 & 6,240 \\
\hline
\end{tabular}

${ }^{a}$ Contributed the following, in $\mathrm{mg} / \mathrm{kg}$ of diet: $\mathrm{Zn}, 160 ; \mathrm{Fe}, 80 ; \mathrm{Mn}, 44 ; \mathrm{Cu}, 8 ; \mathrm{Co}, .8 ; \mathrm{I}, 1.2$.

${ }^{b}$ Contributed the following/kg of diet: vitamin A, 5,500 USP; vitamin $D_{3}, 440$ ICU; vitamin E, 22 IU; riboflavin, $2.9 \mathrm{mg}$; pantothenic acid, $22 \mathrm{mg}$; niacin, $22 \mathrm{mg}$; choline chloride, $220 \mathrm{mg}$ or $770 \mathrm{mg}$; vitamin $\mathrm{B}_{12}, 22 \mu \mathrm{g}$; menadione sodium bisulfite, $2.2 \mathrm{mg}$; ethoxyquin, $4.4 \mathrm{mg}$, in a ground corn carrier.

${ }^{c}$ Calculated. 
diets were fed ad libitum for the duration of the 21-d lactation period. After parturition, cornstarch was not added to the diets without tallow.

Pig weights were recorded at birth and on d 7,14 and 21 . No creep feed was offered to the pigs during the study, but they had access to the sow's diet.

The data were analyzed by an appropriate application of the least-squares analysis of variance procedure according to the Statistical Analysis System (Barr et al., 1976). The main effects of tallow, choline chloride and their respective interactions were evaluated using sows within trial and tallow-choline chloride subclass as the error term.

Exp. 2. A second study was conducted to measure the effect of energy source on milk composition and yield. Twelve crossbred, thirdparity sows were allotted to the control or tallow supplemented diets each with $770 \mathrm{mg} / \mathrm{kg}$ added choline chloride. The dietary treatments were initiated on d 100 of gestation and maintained through a 20-d lactation period. Three days following parturition, litter size was standardized to nine pigs and maintained thereafter by replacing any pig that died with a pig of similar age and weight. The milk yield of each sow was determined on d 12 and 19 by weighing the pigs at hourly intervals before and after nursing. The procedures used were those described by Lewis et al. (1978). The length of time for assessment of milk yield was based on the report by Mahan et al. (1971). The first $2 \mathrm{~h}$ were regarded as introductory in order to acclimate the sow and litter to the process. Data on these nursings were recorded but were not included in the calculation of daily milk yield. Milk yield was determined by multiplying the yield obtained during the next $6 \mathrm{~h}$ by four. Care was taken to account for urinary and fecal losses during the weigh period.

Milk samples were obtained from the sows at parturition (appearance of the first pig) and on

TABIE 2. EFFECT OF TALLOW AND CHOLINE ADDITION TO THE GESTATION-LACTATION DIET OF SOWS ON LACTATION DIET INTAKE, PIG SURVIVAL AND PREWEANING GROWTH (EXP. 1)

\begin{tabular}{|c|c|c|c|c|}
\hline \multirow[b]{3}{*}{ Item } & \multicolumn{2}{|c|}{$0 \%$ tallow } & \multicolumn{2}{|c|}{$8 \%$ tallow } \\
\hline & \multicolumn{4}{|c|}{ Choline chloride, $\mathrm{mg} / \mathrm{kg}$} \\
\hline & 220 & 770 & 220 & 770 \\
\hline \multicolumn{5}{|l|}{ Dam } \\
\hline No. litters & 48 & 46 & 46 & 48 \\
\hline Lactation feed intake, $\mathrm{kg} / \mathrm{d}$ & 5.65 & 5.50 & 5.39 & 5.46 \\
\hline \multicolumn{5}{|l|}{ Pigs - birth } \\
\hline Total born/litter & 9.8 & 9.3 & 10.0 & 9.5 \\
\hline Stillborn/litter & .3 & .3 & .6 & .6 \\
\hline Born alive/litter & 9.5 & 9.0 & 9.4 & 8.9 \\
\hline Avg birth weight, $\mathrm{kg}$ & 1.50 & 1.55 & 1.49 & 1.50 \\
\hline Avg litter weight, $\mathrm{kg}$ & 14.25 & 13.95 & 14.01 & 13.35 \\
\hline \multicolumn{5}{|l|}{ Pigs $-14 \mathrm{~d}$} \\
\hline No. alive/litter & 8.8 & 8.4 & 8.8 & 8.4 \\
\hline Survival, \%b & 92.7 & 93.8 & 93.8 & 95.4 \\
\hline Avg weight, kg & 4.28 & 4.47 & 4.52 & 4.58 \\
\hline Avg litter weight, $\mathrm{kg}$ & 37.66 & 37.55 & 39.78 & 38.47 \\
\hline \multicolumn{5}{|l|}{ Pigs $-21 d$} \\
\hline No. alive/litter & 8.7 & 8.3 & 8.7 & 8.3 \\
\hline Survival, $\% \mathrm{~b}$ & 92.1 & 92.9 & 93.3 & 94.7 \\
\hline Avg weight, kg & 5.97 & 6.27 & 6.21 & 6.47 \\
\hline Avg litter weight, $\mathrm{kg}$ & 51.94 & 52.04 & 54.03 & 53.70 \\
\hline
\end{tabular}

\footnotetext{
${ }^{a}$ Least-squares means.

${ }^{b}$ Percentage of live pigs farrowed.
} 
d 9 and 18. Sixty international units of oxytocin were injected im to affect milk release and 50 to $75 \mathrm{ml}$ of milk was obtained from four to six glands by manual expression. Each gland contributed approximately the same proportion to the sample. Samples were analyzed for total solids, fat and protein (percentage $N \times 6.38$ ) according to AOAC (1975) procedures.

Milk yield and composition data were analyzed statistically by an analysis of variance procedure appropriate for the split-plot design (Barr et al., 1976). Response surface analysis was performed on composition data over time using coefficients appropriate for equally spaced intervals (Snedecor and Cochran, 1967).

\section{Results and Discussion}

The effects of the four dietary treatments on lactation feed intake of the sow and preweaning pig survival and growth are presented in table 2 . No significant differences due to treatment were observed for any of the criteria evaluated. In addition, no tallow $x$ choline interaction was observed, which indicates that additional choline in the tallow supplemented diet did not result in a different response from that obtained with tallow alone. This is in agreement with the data of Seerley et al. (1980) but in contrast to the results of Cast et al. (1977). In the present experiment, however, the rate of survival was markedly higher than that observed in the experiment of Cast et al. (1977) and it would be difficult to improve upon.

The data were pooled and the main effects of tallow and choline level are presented in table 3. During lactation, sows fed tallow-supplemented diets consumed an average of 5.4 $\mathrm{kg}$ of diet daily as compared to $5.6 \mathrm{~kg}$ by sows in the control group but this difference was not significant. This may reflect an increase in the caloric density of the tallow-supplemented diet. Other researchers have reported a reduction in

TABLE 3. LACTATION DATA POOLED WITHIN LEVEL OF TALLOW OR CHOLINE CHLORIDE (EXP. 1)a

\begin{tabular}{|c|c|c|c|c|}
\hline \multirow[b]{2}{*}{ Item } & \multicolumn{2}{|c|}{$\begin{array}{c}\text { Choline chloride, } \\
\mathrm{mg} / \mathrm{kg}^{\mathrm{b}}\end{array}$} & \multicolumn{2}{|c|}{ Tallow, \%c } \\
\hline & 220 & 770 & 0 & 8 \\
\hline \multicolumn{5}{|l|}{ Dam } \\
\hline No. litters & 94 & 94 & 94 & 94 \\
\hline Lactation feed intake, $\mathrm{kg} / \mathrm{d}$ & 5.53 & 5.48 & 5.58 & 5.43 \\
\hline \multicolumn{5}{|l|}{ Pigs - Birth } \\
\hline Total born/litter & 9.9 & 9.4 & 9.6 & 9.7 \\
\hline Stillborn/litter & .4 & .4 & .3 & .6 \\
\hline Born alive/litter & 9.5 & 9.0 & 9.3 & 9.1 \\
\hline Avg birth weight, $\mathrm{kg}$ & 1.49 & 1.52 & 1.52 & 1.50 \\
\hline Avg litter weight, $\mathrm{kg}$ & 14.15 & 13.69 & 14.10 & 13.68 \\
\hline \multicolumn{5}{|l|}{ Pigs - $14 d$} \\
\hline No. alive/itter & 8.8 & 8.4 & 8.6 & 8.6 \\
\hline Survival, \%d & 93.2 & 94.6 & 93.2 & 94.6 \\
\hline Avg weight, $\mathbf{k g}$ & 4.40 & 4.53 & 4.37 & 4.55 \\
\hline Avg litter weight, $\mathrm{kg}$ & 38.72 & 38.05 & 37.58 & 39.13 \\
\hline \multicolumn{5}{|l|}{ Pigs - 21d } \\
\hline No. alive/litter & 8.7 & 8.3 & 8.5 & 8.5 \\
\hline Survival, \%d & 92.7 & 93.8 & 92.5 & 94.0 \\
\hline Avg weight, kg & 6.09 & 6.37 & 6.11 & 6.35 \\
\hline Avg litter weight, $\mathrm{kg}$ & 52.98 & 52.87 & 51.94 & 53.97 \\
\hline
\end{tabular}

${ }^{2}$ Least-squares means.

${ }^{b}$ Data pooled across level of tallow.

CData pooled across level of choline chloride.

$d_{\text {Percentage of live pigs farrowed. }}$ 
daily feed intake due to the addition of fat to the diet (Cast et al., 1977; Boyd et al., 1978; Allee and Salava, 1978; Pollmann et al., 1980).

Survival to $21 \mathrm{~d}$ did not differ significantly between pigs from sows receiving tallow (94.0\%) and those from sows receiving the control diet $(92.5 \%)$. Pigs from sows receiving tallow, however, had a slightly but consistently higher rate of survival in each instance than their choline counterparts (table $2 ; 93.3$ vs $92.1 \%$ and 94.7 vs $92.9 \%$ ) with similar numbers of pigs born alive within each comparison. The level of preweaning survival was high and little opportunity for improvement existed. The results of these data are consistent with Moser and Lewis (1980) who summarized existing data and concluded that inclusion of fats or oils in gestation-lactation diets improves rate of survival.

The addition of tallow to the maternal diet did not significantly affect birth weight ( 1.50 vs $1.52 \mathrm{~kg}$ ) or $21 \mathrm{~d}$ weight of pigs, although there was a trend toward slightly heavier pigs ( 6.35 vs
$6.11 \mathrm{~kg})$ and litters (53.97 vs $51.94 \mathrm{~kg}$ ) after a 21-d lactation period in pigs nursing sows fed tallow (table 3 ). There were similar numbers of pigs at birth and the same average litter size at 14 (8.6) and $21 \mathrm{~d}(8.5)$. A similar observation has been reported (Okai ct al., 1977) for pigs whose dams were fed a $10 \%$ tallow diet ad libitum during late gestation. In previous experiments in which 15 or $20 \%$ tallow diets were fed through a 14-d lactation period (Cast et al., 1977; Boyd et al., 1978), pig weights appeared to be similar to those in a control group.

The trend toward greater weaning weights for pigs nursing sows that were fed dietary tallow throughout lactation may be explained on the basis of milk composition and yield. During the early postnatal phase of growth and development, young pigs are largely dependent upon their dams for nourishment. Therefore, milk yield and milk composition are associated with the rate of growth and development of the young pig (Fahmy, 1972; Lewis et al., 1978).

TABLE 4. EFFECT OF ENERGY SOURCE ON MILK YIELD AND COMPOSITION OF THIRD-PARITY SOWS (EXP. 2)a

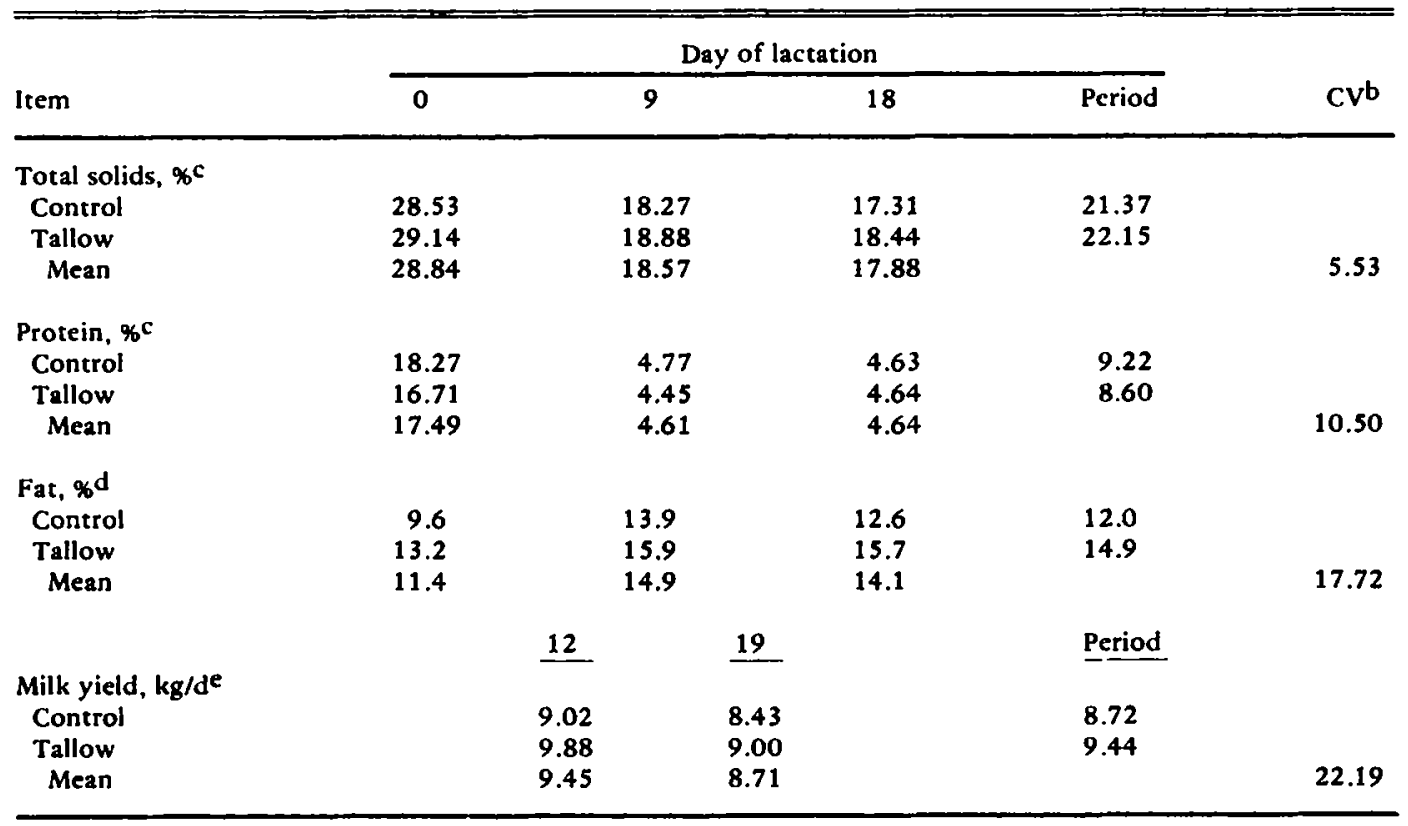

${ }^{a}$ Six sows/dietary treatment.

${ }^{b}$ Coefficient of variation (percentage) was calculated from the sow-within-treatment mean squares.

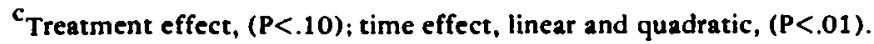

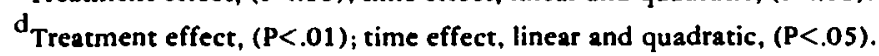

Time effect, $(P<.05)$. 
Milk yield and composition data are summarized in table 4. Measurement of milk yield, though difficult and tedious, is an important criterion of response because nutritional status of the sow does exert an influence (Lewis and Speer, 1973). The mean yield for the period was greater for sows fed tallow $(9.44 \mathrm{~kg} / \mathrm{d})$ than for sows receiving the control diet $(8.72 \mathrm{~kg} / \mathrm{d})$, although the difference was not significant. Kruse et al. (1977) and Pettigrew (1978) have each reported a similar increase. Sows in both groups had a higher $(\mathrm{P}<.05)$ level of production $12 \mathrm{~d}$ postpartum $(9.45 \mathrm{~kg} / \mathrm{d})$ than at 19 $\mathrm{d}(8.71 \mathrm{~kg} / \mathrm{d})$.

Sows receiving a proportion of their dietary energy in the form of tallow maintained a higher concentration of total milk solids (22.15\%, $\mathrm{P}<.10)$ and fat $(14.9 \%, \mathrm{P}<.01)$ throughout the lactation period than did sows in the control group $(21.37$ and $12.0 \%$, respectively). Dramatic changes in the two components occurred during the lactation period; however, sows in both dietary treatment groups responded similarly (i.e., there was no treatment $x$ time interaction). Total milk solids contents decreased quadratically $(\mathrm{P}<.01)$, and concurrent with declining solids there was an increase in fat content (quadratic response, $\mathrm{P}<.05$ ).

The protein content of the colostrum and milk, averaged across time, was lower $(P<.10)$ for sows receiving tallow than for those fed the control diet ( 8.60 vs $9.22 \%)$. The difference, however, appeared to be attributable to the colostrum samples because values obtained on d 9 and 18 were similar for the two treatment groups.

Increases in colostrum and milk fat due to dietary lipid addition have been reported previously (Seerley et al., 1974, 1978a,b; Friend, 1974; Cast et al., 1977; Boyd et al., 1978). Seerley et al. (1978b) reported that increased fat content of colostrum was associated with increased energy density but observed no difference in protein content compared to a control group which was fed isocalorically. Greater fat content and thus energy density is important to smaller, less competitive pigs which nurse less frequently than larger pigs (Hartsock and Graves, 1976; Boyd et al., 1978) since the initial 12 to $24 \mathrm{~h}$ is a period of critical energy status (i.e., glucose).

\section{Literature Cited}

Allee, G. L. al:- J. Salava. 1978. Effect of adding fat to diets during late gestation and lactation. Kansas State Agr. Exp: Sta. Rep. 342. p 29.

AOAC. 1975. Official Methods of Analysis (12th Ed.). Association of Official Analytical Chemists, Washington, DC.

Barr, A. J., J. H. Goodnight, J. P. Sall and J. T. Helwig. 1976. A User's Guide to SAS-76. SAS Institute, Inc., Raleigh, NC.

Boyd, R. D., B. D. Moser, E. R. Peo, Jr. and P. J. Cunningham. 1978. Effect of energy source prior to parturition and during lactation on piglet survival and growth and on milk lipids. J. Anim. Sci. 47:883.

Cast, W. R., B. D. Moser, E. R. Peo, Jr. and P. J. Cunningham. 1977. Fat, choline and thyroprotein additions to the diet of lactating swine. J. Anim. Sci. 45 (Suppl. 1):80.

Fahmy, M. H. 1972. Comparative study of colostrum and milk composition of seven breeds of swine. Can. J. Anim. Sci. 52:621.

Friend, D. W. 1974. Effect on the performance of pigs from birth to market weight of adding fat to the lactation diet of their dams. J. Anim. Sci. 39: 1073.

Hartsock, T. G. and H. B. Graves. 1976. Neonatal behavior and nutrition-related mortality in domestic swine. J. Anim. Sci. 42:235.

Kruse, P. E., V. Danielsen, H. E. Nielsen and K. Christensen. 1977. The influence of different dietary levels of linoleic acid on reproductive performance and fatty acid composition of milk fat and plasma lipids in pigs. Acta Agr. Scand. 27:289.

Lewis, A. J. and V. C. Speer. 1973. Lysine requirement of the lactating sow. J. Anim. Sci. 37:104.

Lewis, A. J., V. C. Speer and D. G. Haught. 1978. Relationship between yield and composition of sows' milk and weight gains of nursing pigs. J. Anim. Sci, 47:634.

Mahan, D. C., D. E. Becker, H. W. Norton and A. H. Jensen. 1971. Milk production in lactating cows and time lengths used in evaluating milk production estimates. J. Anim. Sci. 33:35.

Moser, B. D. and A. J. Lewis. 1980 . Adding fat to sow diets - an update. Feedstuffs 52(9):36.

Okai, D. B., F. X. Aherne and R. T. Hardin. 1977. Effects of sow nutrition in late gestation on the body composition and survival of the neonatal pig. Can. J. Anim. Sci. 57:439.

Pettigrew, J. E. 1978. Supplemental fat in sow diets. Proc. Pacific NW Pork Exposition, Washington State Univ. p 59.

Pollmann, D. S., D. M. Danielson, M. A. Crenshaw and E. R. Peo, Jr. 1980. Long term effects of dietary additions of alfalfa and tallow on sow reproductive performance. J. Anim. Sci. 51:294.

Seerley, R. W., F. M. Griffin and H. C. McCampbell. 1978a. Effect of sow's dietary energy source on sow's milk and piglet carcass composition. J. Anim. Sci. 46:1009.

Seerley, R. W., J. S. Maxwell and H. C. McCampbell. $1978 \mathrm{~b}$. A comparison of energy sources for sows and subsequent effects on piglets. J. Anim. Sci. 47:1114.

Seerley, R. W., T. A. Pace, C. W. Foley and R. D. Scarth. 1974. Effect of energy intake prior to 
parturition on milk lipids and survival rate, thermostability and carcass composition of piglets. J. Anim. Sci. 38:64.

Seerley, R. W., R. A. Snyder, H. C. McCampbell and M. T. Coffey. 1980. Source of energy for sow and effect on baby pig survival. J. Anim. Sci. 51 (Suppl. 1):220.
Snedecor, G. W. and W. G. Cochran. 1967. Statistical Methods (6th Ed.). Iowa State University Press, Ames.

Stanton, H. C. and J. K. Carroll. 1974. Potential mechanisms responsible for prenatal and perinatal mortality or low viability of swine. J. Anim. Sci. 38:1037. 